\title{
Diversity and ecological role of insect flower visitors in the pollination of mangroves from the Indian Sundarbans
}

\author{
Udipta Chakraborti ${ }^{1}$, Bulganin Mitra ${ }^{2}$ and Kakali Bhadra ${ }^{1, *}$ \\ ${ }^{1}$ Department of Zoology, University of Kalyani, Kalyani 741 235, India \\ ${ }^{2}$ RKMVC College, Rahara, Khardaha 700 118, India
}

Sundarban Biosphere Reserve is one of the most important mangrove zones with a vast range of floral and faunal diversity. The present study explores the plant-pollinator relationship among four true mangrove plants, viz. Avicennia officinalis, Avicennia marina, Aegiceras corniculatum and Aegialitis rotundifolia, and also includes insect visitor diversity and foraging activities of common insect flower visitors of these plants with their efficiency as pollinators. Though each plant is self-compatible for pollination, the activity of flower visitors helped with superior reproductive success. Among the common five visitors, viz. Apis dorsata, Apis mellifera, Chrysomya megacephala, Danaus chrysippus and Micraspis discolor, A. dorsata showed the highest visitation rate (VR) for each plant and $M$. discolor showed the lowest VR but highest handling time (HT) in all the four mangrove plants. Each flower visitor showed significantly different VR among the plants. In the case of HT, only A. mellifera showed significant variation among plants. $A$. dorsata and $A$. mellifera showed maximum pollen carrying efficiency compared to the others. These findings emphasize the role of insect flower visitors in pollination, leading to the perquisite for the protection of mangroves of the Indian Sundarbans.

Keywords: Foraging efficiency, handling time, insect flower visitors, mangroves, visitation rate.

MANGROVES, the only halophyte-dominated, intertidal ecosystem situated at the convergence of land and sea, have been heavily used traditionally for the basic needs of humans such as food, timber, fuel and medicine. Mangroves presently occupy about $181,000 \mathrm{sq}$. $\mathrm{km}$ of the tropical and subtropical coastline worldwide. Approximately one-third of mangrove forests in the world has been lost over the past 50 years ${ }^{1}$. The distribution of this unique ecosystem in the intertidal zones of tropical and subtropical regions of the world is fragile but diversified $^{2,3}$. Hence conservation of this ecosystem should be the primary task for ecologists. Though mangrove forest holds less species richness than other tropical forests and

\footnotetext{
*For correspondence. (e-mail: kakali_bhadra2004@yahoo.com)
}

is architecturally simpler than rainforests, but because of its unique ecosystem structure it is highly productive and holds a great diversified faunal resource ${ }^{1,4}$. Mangrove flora and vegetation were first studied by Hamilton and Snedakar ${ }^{5}$ and later by Tomlinson ${ }^{6}$. The focus of research regarding mangrove reproductive biology has almost exclusively been on the fruit dispersal stage ${ }^{7}$, but surprisingly little is known about its pollination biology. The plant-pollinator relationship is one of the important phenomena in reproduction of the angiosperm flowers, and it is often labelled as a tightly coevolved and mutualistic relationship ${ }^{8}$. With the variations in flower morphology such as size, colour, scent, nectar and pollen, the angiosperm flowers encourage diversity in pollinating species ${ }^{9}$. Pollination ecology plays a major role in the characterization of floral structure and the behaviour of foraging animals, which provides information about the structure of the plant community and adaptability of the visitors to flowers related to the mechanism of pollination ${ }^{10,11}$. Pollinator plays an important role in the breeding mechanism of some plants ${ }^{12}$. The diversified flower visitors of mangroves mostly selected with the generalized pollination system. Due to remote locations, harsh environmental conditions and less availability of pollination resources, insect visitors are associated with plants with a broad spectrum, i.e. most of the plants are not dependent on a particular type of pollinator, but in some cases they may be dependent upon some class of the pollinators ${ }^{13}$.

Among all the mangrove forests in the world, Sundarbans, which occupies about 10,000 sq. km (UNESCO; https://whc.unesco.org/en/list/798/), is the largest and one of the most productive and taxonomically diversified mangrove forests. With a unique ecosystem, this forest is divided between two countries, viz. Bangladesh and India. The Indian part consists of almost $40 \%$ of the forest and the rest is in Bangladesh ${ }^{14,15}$. This World Heritage Site consists of 24 true or major mangroves ${ }^{16}$.

The present study focuses on the diversity of insect pollinators of four true mangrove species, viz. Avicennia officinalis (AO), Avicennia marina (AM), Aegiceras corniculatum (AC) and Aegialitis rotundifolia (AR) from the Indian Sundarbans. The information generated from this study will serve as baseline data regarding foraging 
activity of the common flower visitors that will ultimately help in the identification of the most efficient flower visitors/pollinators of these plants from the Sundarbans.

\section{Materials and methods}

\section{Studied plants}

The study was performed on four ecologically important true Indian mangroves, viz. AO, AM, AC and AR on the basis of the pollination system and ecological role of insects in their pollination. Only a few studies have been done on the insect pollination of these plant species from the Sundarbans mangrove $\mathrm{e}^{3,17-19}$.

Avicennia officinalis Linnaeus (family Aviceniaceae) is an evergreen and dominant mangrove species. It is a moderate size tree with height of almost 15-20 m, stem up to $100 \mathrm{~cm}$ in diameter, bark smooth and whitish-grey, pneumatophores many and simple. Leaves are 6-10 $\mathrm{cm} \times$ $3-6 \mathrm{~cm}$ in size with broadly ovate-oblong structure. The flowering season is early May to early July. The starshaped flower (almost $11 \mathrm{~mm}$ long and $8 \mathrm{~mm}$ in diameter) is yellow in colour, and panicle inflorescence with five sepals. Pollen is creamy in colour ${ }^{20,21}$.

Avicennia marina (Forsk.) Vierh. (family Avicenniaceae) is a tree with irregular branches. It grows to more than $8 \mathrm{~m}$ in height, bark is smooth yellowish-brown in colour, leaves elliptic-oblong in shape and 3-6 $\mathrm{cm} \times 2-$ $2.5 \mathrm{~cm}$ in size with the upper portion of the leaves showing pale green colour. The flowering season is late April to early July. The size of the flower is almost $6 \mathrm{~mm}$ long and $4 \mathrm{~mm}$ in diameter and is pale or orange-yellow in colour. The flower is complete bisexual, regular, cyclic with four petals and five sepals ${ }^{21-23}$.

Table 1. Study areas in Sundarban Biosphere Reserve, India

\begin{tabular}{|c|c|}
\hline Islands & Study areas \\
\hline Gosaba Island & $\begin{array}{l}\text { Pakhirala }\left(22^{\circ} 07.959^{\prime} \mathrm{N}, 088^{\circ} 49.542^{\prime} \mathrm{E}\right) \\
\text { Jotirampur }\left(22^{\circ} 09.099^{\prime} \mathrm{N}, 088^{\circ} 50.728^{\prime} \mathrm{E}\right) \\
\text { Paschimpara, Dulki }\left(22^{\circ} 07.956^{\prime} \mathrm{N}, 088^{\circ} 48.946^{\prime} \mathrm{E}\right)\end{array}$ \\
\hline Satjelia Island & $\begin{array}{l}\text { Binapani }\left(22^{\circ} 08.507^{\prime} \mathrm{N}, 088^{\circ} 51.610^{\prime} \mathrm{E}\right) \\
\text { Satjelia Bazar }\left(22^{\circ} 10.063^{\prime} \mathrm{N}, 088^{\circ} 52.504^{\prime} \mathrm{E}\right) \\
4 \text { No. Satjelia }\left(22^{\circ} 09.328^{\prime} \mathrm{N}, 088^{\circ} 53.552^{\prime} \mathrm{E}\right)\end{array}$ \\
\hline Bali Island & $\begin{array}{l}\text { Vidya forest }\left(22^{\circ} 05.681^{\prime} \mathrm{N}, 088^{\circ} 45.872^{\prime} \mathrm{E}\right) \\
9 \text { No. Gheri }\left(22^{\circ} 05.335^{\prime} \mathrm{N}, 088^{\circ} 45.552^{\prime} \mathrm{E}\right) \\
\text { Banidhal }\left(22^{\circ} 08.150^{\prime} \mathrm{N}, 088^{\circ} 45.628^{\prime} \mathrm{E}\right)\end{array}$ \\
\hline Bakkhali Island & $\begin{array}{l}\text { Bijoybati (Kalisthan 1) }\left(21^{\circ} 35.110^{\prime} \mathrm{N}, 088^{\circ} 17.102^{\prime} \mathrm{E}\right) \\
\text { Kalisthan }\left(21^{\circ} 35.413^{\prime} \mathrm{N}, 088^{\circ} 17.153^{\prime} \mathrm{E}\right) \\
\text { Bakkhali }\left(21^{\circ} 35.028^{\prime} \mathrm{N}, 088^{\circ} 17.665^{\prime} \mathrm{E}\right)\end{array}$ \\
\hline Sagar Island & $\begin{array}{l}\text { Gangasagar Colony }\left(21^{\circ} 38.265^{\prime} \mathrm{N}, 088^{\circ} 04.946^{\prime} \mathrm{E}\right) \\
\text { Pulbari, Paschimpara }\left(21^{\circ} 51.951^{\prime} \mathrm{N}, 088^{\circ} 07.370^{\prime} \mathrm{E}\right) \\
\text { Shikarpur }\left(21^{\circ} 48.462^{\prime} \mathrm{N}, 088^{\circ} 10.038^{\prime} \mathrm{E}\right)\end{array}$ \\
\hline
\end{tabular}

Aegiceras corniculatum (L.) Blanco (family Myrsinaceae) is characterized as a small trees of height up to $6 \mathrm{~m}$ and $20 \mathrm{~cm}$ in diameter. Leaves of this plant are 4$8 \mathrm{~cm} \times 2-4 \mathrm{~cm}$ in size, ovate-oblong. Flowering is in late February to early April. Aluri ${ }^{20}$ reported the flowering season as March to May. Flower is almost $15 \mathrm{~mm}$ long and $13 \mathrm{~mm}$ diameter, small in size, star-shaped, white in colour, number of sepals is five and number of petals is also five with umbel inflorescence. Pollen is white in colour and powdery ${ }^{20,21}$.

Aegialitis rotundifolia Roxb. (family Plumbaginaceae) is characterized as a shrub or small tree of height up to $3 \mathrm{~m}$ and $20 \mathrm{~cm}$ in diameter. Leaves are $2.5-9 \mathrm{~cm} \times 3-9 \mathrm{~cm}$ in size, rounded or broadly ovate or sub-orbicular. Flowering season is during late February to early April. Flower is almost $18 \mathrm{~mm}$ long and $11 \mathrm{~mm}$ diameter, white in colour, five sepals with five lobed calyx ${ }^{21-24}$.

\section{Study area}

The study was performed in the mangrove ecosystem of Sundarban Biosphere Reserve, South 24 Parganas district, West Bengal, India, to understand the interaction between the plant and flower visitors for cross-pollination. Five islands were selected for the study, namely Gosaba, Satjelia, Bali, Bakkhali and Sagar. Among these, three study areas from each island were selected for further analysis (Table 1, Figure 1). The study areas were selected on the basis of availability and accessibility of the studied plants. Map was constructed using QGIS_3.4 Madeira software ${ }^{25}$.

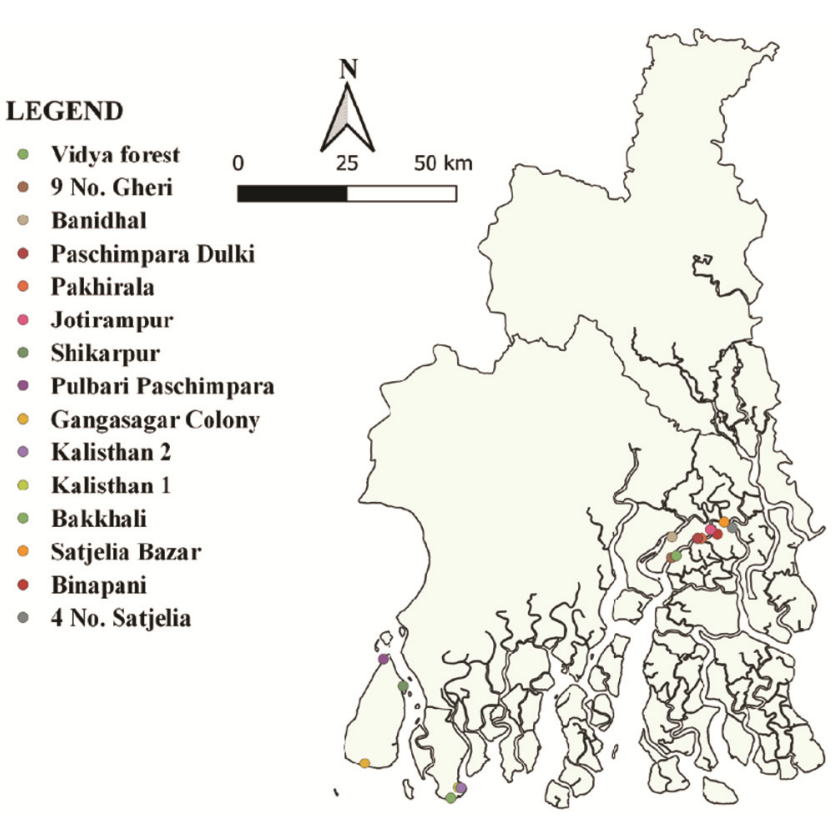

Figure 1. Map of South 24 Parganas, West Bengal, India, including the study areas. 


\section{Sampling technique and study period}

An area of 500 sq. $\mathrm{m}$ ( $10 \mathrm{~m}$ width $\times 50 \mathrm{~m}$ length $)$ was marked from each study area, and from each marked area three individuals of each plant species were selected randomly for analysis. The study was conducted during the flowering to fruiting season of the respective plants during 2016-2018. Each plant individual was monitored for the time period from 6 am to $6 \mathrm{pm}$ with $2 \mathrm{~h}$ intervals, thrice in a week. After obtaining the necessary data for the study, the flower visitors of the respective plants were photographed (if possible) and collected with the help of round-headed insect net. Collection was not done for the insects which were identifiable on field. The collection, preservation, setting and pinning procedure was followed according to Jonathan and Kulkarni ${ }^{26}$. For identification of flower visitors, the specimens was taken to the Zoological Survey of India, Kolkata.

\section{Breeding experiment}

Breeding experiment was performed to visualize the effect of pollinators on the reproductive success of the studied plants. From each plant individual four branches with maximum number of mature budding conditions were chosen randomly, tagged and among them two branches were bagged. Buds were counted for both conditions in each selected branch and fruits were counted at the end of the experiment for each respective branch. The bagged condition denotes the self or closed pollination system and the unbagged condition denotes the cross- or open pollination system. All the branches studied for the breeding experiment were constantly monitored till the fruit set appeared.

\section{Data collection for foraging efficiency of flower visitors}

The flower visitors were continuously monitored for a maximum time of $1 \mathrm{~min}$ for the respective plant species. For each observation period, total time spent on flower (TF; time from touching or landing on the flower to departure from the flower by the insect) and total observation time (TT; time spent on a flower and time of flight to the next flower of the same plant species) were taken for the targeted flower visitors with the help of separate stopwatches. The total number of flower visitations during an observation period by an individual of an insect species was also recorded (NF). From these data, two parameters for the estimation of foraging efficiency were analysed: (i) Visitation rate (VR) - average number of flowers visited by an insect per unit of time (NF/TT); in the present study data for VR were analysed in $1 \mathrm{~min}$ for each individual of an insect species. (ii) Handling time
(HT) - average time spent on a single flower by an insect $(\mathrm{TF} / \mathrm{NF})^{27,28}$.

\section{Data collection for correlation analysis}

To analyse the relationship between insect visitors and bloomed flowers, a correlation analysis was performed. The number of total visitors was counted in $1 \mathrm{~min}$ along with the number of bloomed flowers on a single branch of the respective plant selected randomly. A total of 30 observations were taken for each plant species for this analysis. Correlation graph was plotted using Microcal Origin (version 6.0) software and Microsoft Excel 2007 software. A value $(r)$ close to 1 indicates the stronger relationship between the insect visitors and the bloomed flowers of the plant.

\section{Pollen collection procedure and analysis of pollen carrying capacity}

To study the pollen loading capacity, the insects were captured during the time period from 8 am to $12 \mathrm{pm}$ from the respective plants, then pollen grains were separated from the body of the insect visitors by smooth brushing and washing. For honeybees, the pollen load of corbiculae was separated prior to the brushing or washing. Only the loose pollen grains attached to different body parts of the insect were taken for estimation. The average value of pollen carrying capacity of each insect was measured to understand its pollination efficiency.

\section{Statistical analysis}

Cluster analysis was performed using paired group algorithm (UPGMA) and Jaccard similarity measure, on the basis of presence and absence of insect flower visitors among the studied plant. Similarity and distance index (S\&D index) was also measured using Jaccard similarity measure, where 1 indicates the highest similarity and 0 indicates no similarity. Box plot was used for proper profiling of the range of VR and HT among insect visitors in the studied plants. In each one-way ANOVA, 30 observations from each category were selected randomly and divided into 3 groups (10 observations each). The analysis was performed with average value of each group. The value of ANOVA was tested at 5\% significance level $(P<0.05)$. All statistical analysis was performed using the PAST software (version-3.19) ${ }^{29}$.

\section{Results and discussion}

\section{Self and cross-pollination in the breeding system}

The breeding mechanism of plants is related to pollinator attraction, where the self-pollinating plant species are less 
Table 2. Breeding experiment analysis of four mangroves

\begin{tabular}{lcc}
\hline Plants & $\begin{array}{c}\text { Close pollination } \\
\text { (bagged; \%) }\end{array}$ & $\begin{array}{c}\text { Open pollination } \\
\text { (unbagged; \%) }\end{array}$ \\
\hline Aegiceras corniculatum (AC) & 43.2 & 50.4 \\
Aegialitis rotundifolia (AR) & 39.2 & 64.1 \\
Avicennia officinalis (AO) & 22.9 & 63.8 \\
Avicennia marina (AM) & 19.6 & 59.6 \\
\hline
\end{tabular}

capable of interaction with the pollinators than the crosspollinated plants ${ }^{12,30}$. In this study, each of the studied plant species is compatible for both kinds of pollination, but reproductive success is better in cross-pollination. In case of success rate of cross-pollination, AR was associated with the highest percentage of fruit set (64.1), whereas AC with the lowest. However, in the context of self-pollination success, AC was leading with the highest percentage of fruit set (43.2). Both plants from the genus Avicennia, because of protandrous condition, were inclined to cross-pollination than self-pollination (Table 2). Pandit and Choudhury ${ }^{12}$ reported that AC supports the morphology for self-pollination, which may lead them to be self-fertilized and less dependable to the crosspollination, but they also reported a great variety of insect flower visitors from this plant. However, the present study showed a slightly higher range of cross-pollination in these plants than self-pollinated fruit set. Coupland et $a l .{ }^{31}$ demonstrated that for pollination of AM, pollen vectors are of greater importance. They also indicated that fruit set of AM is preferably resource-limited. Solomon Raju et al. $^{32}$ also noted that both AO and AM have the ability to self-pollinate, but they also emphasized the functional role of insect pollinators for these plants. The self-compatibility in the pollination system of AR was also highlighted ${ }^{24}$. In the context of AR pollination system, these plants also reflect the self-compatibility, but cross-pollination increases the fruit set.

\section{Diversity of insect flower visitors of mangroves}

A total of 38 insect species from four orders were recorded as visitors from the studied plants. Among them, order Diptera holds the highest position with 14 species, followed by Lepidoptera and Hymenoptera with 12 and 9 species respectively. Coleoptera was included with the lowest number of species, viz. only three. The highest number of species was reported from AO (27 species), whereas AC was related to only 13 species. The dipterans and coleopterans were strongly related to both Avicennia plant species while lepidopterans were mostly dominant in AR. In case of hymenopetrans insects, both AO and $\mathrm{AC}$ showed higher number of species compared to others (Table 3, Figure 2).

The present study focuses on the five common flower visitors of these plants, viz. Apis dorsata, Apis mellifera,

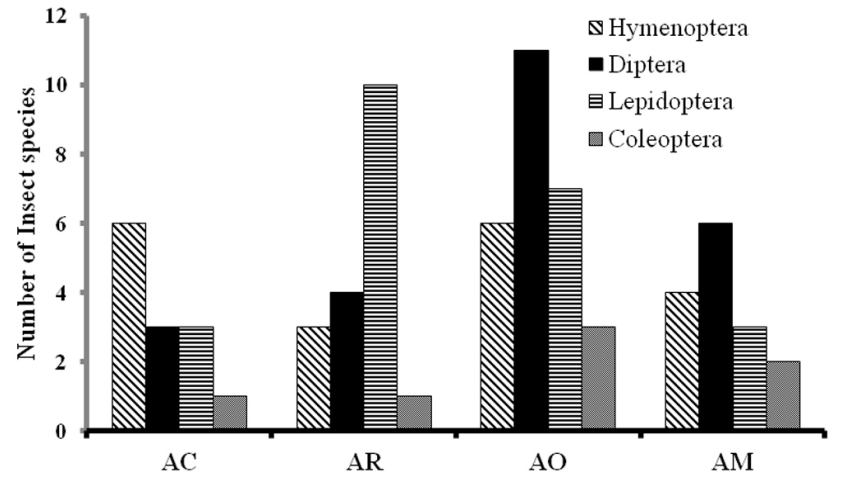

Figure 2. Bar graph of the insect flower visitor species from the studied mangrove plants.

Chrysomya megacephala, Danaus chrysippus and Micraspis discolor. Among them, the most abundant insect flower visitor in these four plants was $M$. discolor and the honey-bee species. As A. mellifera is commonly domesticated in the Sundarbans in the form of apiculture, therefore closer to the apiculture zone the abundance of this species (A. mellifera) was more compared to the wild honey-bee species $A$. dorsata. The abundance of $M$. discolor was comparatively higher almost among all the studied mangrove plants throughout the study areas. The abundance of $C$. megacephala and D. chrysippus was moderate among the four plants. In case of $C$. megacephala, the abundance was least in AR, whereas D. chrysippus was mostly encountered in these plant species. There was no significant variation related to insect visitor abundance among each of the plants during three years of study (AC: $F_{2,6}=0.927, \quad P$-value $-0.44 ; \quad$ AR: $F_{2,6}=0.2 .49 ; P$-value $-0.16 ;$ AO: $F_{2,6}=0.563 ; P$-value 0.59 ; AM: $F_{2,6}=0.25, P$-value -0.77$)$.

\section{Analysis of similarity in species composition}

Regarding flower visitor species composition among the four plants, similarity and distance analysis (Jaccard cluster analysis) indicates that AO and AM have the highest similarity (44\%). Though these two plants differ slightly in blooming time, they bear similar type of floral morphology and therefore insects of the same type serve these plants as flower visitors/pollinators ${ }^{6,32}$. AC and 
Table 3. Flower-visitor insects from four mangrove plants

\begin{tabular}{|c|c|c|c|c|c|}
\hline Order & Species & $\mathrm{AC}$ & AR & $\mathrm{AO}$ & $\mathrm{AM}$ \\
\hline Hymenoptera & Apis (Megapis) dorsata dorsata** & + & + & + & + \\
\hline Hymenoptera & Apis mellifera** & + & + & + & + \\
\hline Hymenoptera & Oreumenoides edwardsii & + & - & - & - \\
\hline Hymenoptera & Campsomeriella $(C$.$) collaris collaris$ & - & - & - & + \\
\hline Hymenoptera & Scolia (Discolia) affinis & + & - & + & - \\
\hline Hymenoptera & Subancistrocerus sichelii & - & - & + & - \\
\hline Hymenoptera & Xylocopa fenestrate & - & - & + & + \\
\hline Hymenoptera & Delta conoideum & + & - & + & - \\
\hline Hymeoptera & Sceliphron sp. & + & + & - & - \\
\hline Diptera & Chrysomya megacephala** & + & + & + & + \\
\hline Diptera & Allobaccha amphithoe & + & - & + & + \\
\hline Diptera & Physiphora aenea & - & - & + & + \\
\hline Diptera & Musca (Musca) domestica & + & - & - & + \\
\hline Diptera & Eristalis arvorum & - & - & + & + \\
\hline Diptera & Sarcophaga dux & - & - & + & - \\
\hline Diptera & Sarcophaga (Iranihindia) martellata & - & - & + & - \\
\hline Diptera & Tabnus striatus & - & - & + & - \\
\hline Diptera & Eristalinus polychromatus & - & - & + & - \\
\hline Diptera & Chrysops dispar & - & + & + & + \\
\hline Diptera & Tinda indica & - & - & + & - \\
\hline Diptera & Cadrema pallida var. bilineata & - & - & + & - \\
\hline Diptera & Dideopsis aegrota & - & + & - & - \\
\hline Diptera & Bactrocera cucurbitae & - & + & - & - \\
\hline Lepidoptera & Euploea core & + & + & + & - \\
\hline Lepidoptera & Danaus chrysippus $* *$ & + & + & + & + \\
\hline Lepidoptera & Tirumala limniace & - & + & + & + \\
\hline Lepidoptera & Catopsilia pyranthe & - & + & + & + \\
\hline Lepidoptera & Junonia almana & - & + & + & - \\
\hline Lepidoptera & Catochrysops strabo & - & + & - & - \\
\hline Lepidoptera & Cepora nerissa & - & + & - & - \\
\hline Lepidoptera & Danaus melanippus & - & + & - & - \\
\hline Lepidoptera & Hypolimnas bolina & + & + & - & - \\
\hline Lepidoptera & Papilio demoleus & - & + & - & - \\
\hline Lepidoptera & Euchrysops cnejus & - & - & + & - \\
\hline Lepidoptera & Melanitis leda & - & - & + & - \\
\hline Coleoptera & Micraspis discolor $* *$ & + & + & + & + \\
\hline Coleoptera & Cicindela (Callytron) limosa & - & - & + & - \\
\hline Coleoptera & Adoretus lacustris & - & - & + & + \\
\hline
\end{tabular}

**Denotes common visitor among the four plants.

Similarity
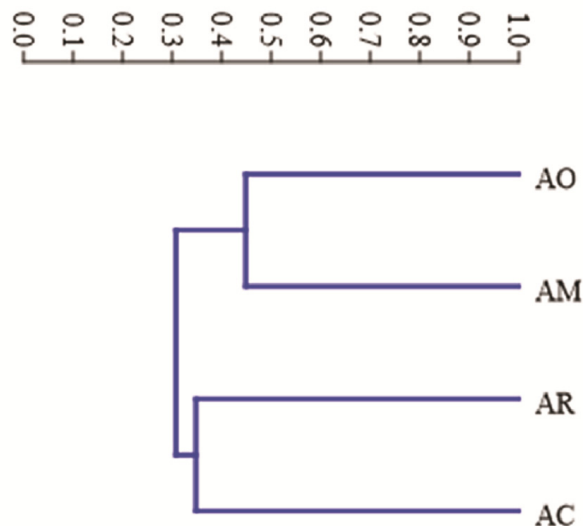

Figure 3. Cluster analysis, Jaccard similarity measure with UPGMA method for four mangrove plants on the basis of their species composition. Here 1 indicates the maximum similarity and 0 indicates no similarity.
AR hold the next position with $34 \%$ similarity in species composition (Figure 3 ).

\section{Correlation analysis between bloomed flowers and visitor abundance}

The relation between bloomed flowers and visitor abundance is important for pollination. In this study, each plant shared a strong positive relation with the insect visitors. Among the four mangroves, AC had the strongest relation with insect visitor abundance $(r=0.80, n=30$, $P<0.05)$. Both AO and AM, showed similar kind of relation with the visitors $(r=0.737, n=30, P<0.05$ for AO, and $r=0.736, n=30, P<0.05$ for AM). However, AR showed comparatively weaker relationship with insect abundance $(r=0.71, n=30, P<0.05$; Figure 4$)$. 

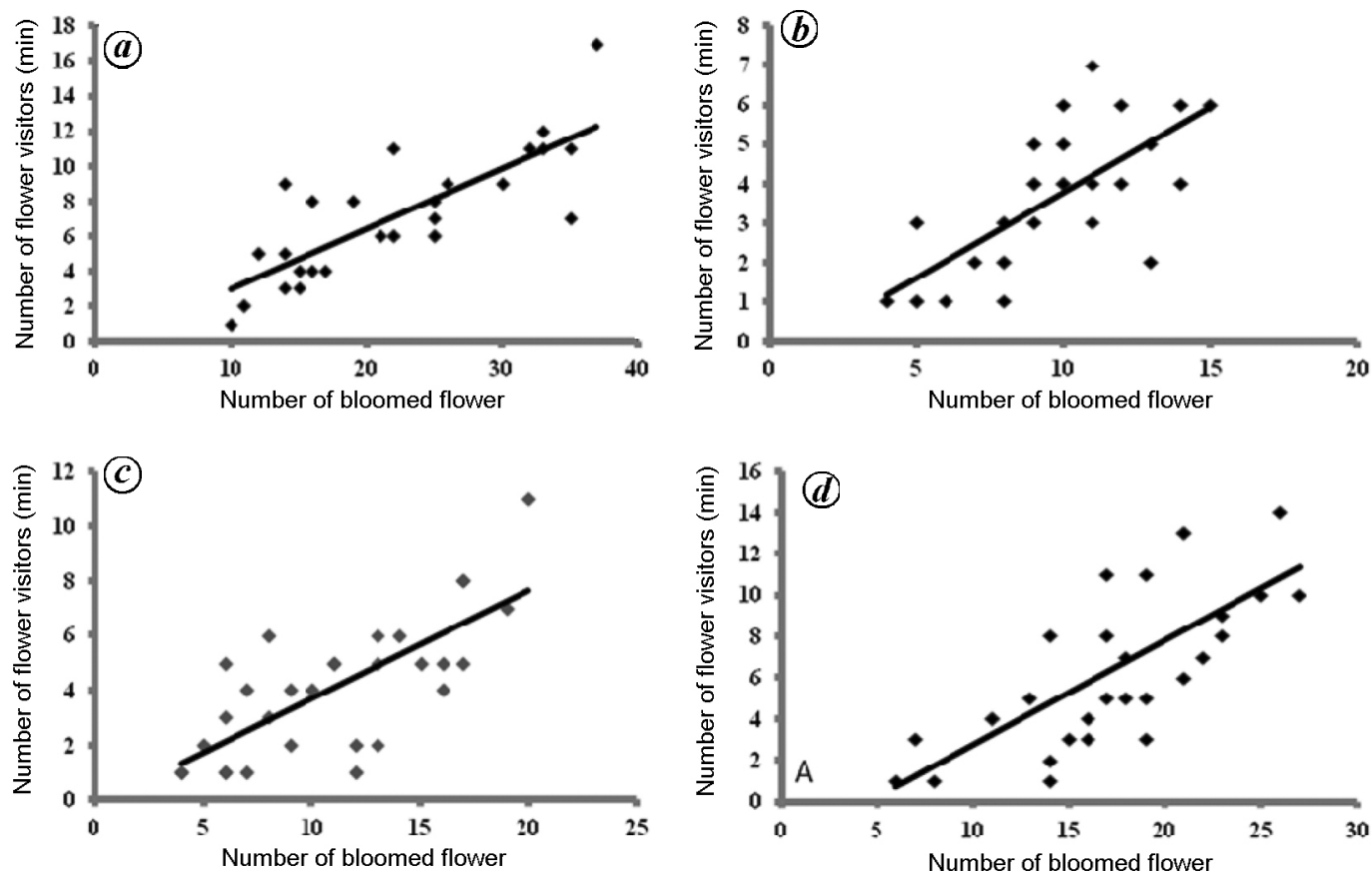

Figure 4. Correlation analysis $(r)$ between the number of visitors/min and the number of bloomed flowers in each of the four studied mangrove plants: a, Aegiceras corniculatum; $\boldsymbol{b}$, Aegialitis rotundifolia; $\boldsymbol{c}$, Avicennia officinalis; d, Avicennia marina. Here $n=30$ ( $n$ is the total number of observations). Values closer to 1 indicate the highest correlation and 0 indicates the lowest correlation.

\section{Effect of visitation rate and handling time in foraging efficiency of flower visitors/pollinators}

In the plant-pollinator system, VR and HT of the pollinating insect play an important role in reproductive success in relation to cross-pollinated angiosperms ${ }^{33}$. Ne'eman et $a l .{ }^{34}$ described visitation frequency as an important component for pollinator performance in plant reproduction.

In the present study, in the context of highest VR among the four plants, $A$. dorsata and $A$. mellifera were reported in $\mathrm{AC}(12.8 \pm 0.70$ and $11 \pm 0.75$ flowers $/ \mathrm{min}$ respectively), $C$. megacephala showed the highest VR in AO (7.3 \pm 0.59 flowers/min), D. chrysippus, the lepidopteran visitor was associated with AR (5.1 \pm 0.32 flow$\mathrm{ers} / \mathrm{min})$ and $M$. discolor $(2.8 \pm 0.29$ flowers $/ \mathrm{min})$ was related to AM (Figure 5). Thus, AC, AO and AM showed a significant difference in VR among their four flower visitors, viz. A. dorsata, A. mellifera, C. megacephala and $D$. chrysippus, but no significant difference was recorded in VR among the flower visitors of AR. M. discolor was excluded from the analysis because of its low VR among all the plants (Table 4). Based on VR analysis of insect visitors among the four plants, each of the flower visitors except $M$. discolor showed significant difference among the four plants (Table 5). VR of pollinators may vary on the basis of different parameters like flower structure, design, colour, size and nectar production. Insect visitation may also vary due to spatial and temporal arrangement in floral display. Due to these reasons, different flower visitors respond differently in their activity with respect to a single plant ${ }^{35}$. In this study, each insect-specific analysis denotes that VR for a single insect significantly differs among the four plants, except $M$. discolor. The information on VR of these flower visitors/ pollinators will help in conservation and management procedures aiming at adequate pollination of these mangrove plants.

Furthermore, it is crucial to monitor HT by a visitor to understand the foraging behaviour. Among the five common flower visitors, HT of $M$. discolor was the highest for all four mangrove plants (Figure 6). In case of plantspecific analysis, significant difference was noted in HT among the remaining four flower visitors, viz. A. dorsata, A. mellifera, C. megacephala and D. chrysippus in each of the studied plants. $M$. discolor was excluded from this analysis because of its high HT throughout the study period (Table 4). In case of visitor-specific analysis, only $A$. mellifera showed significant variation in HT among the four plants (Table 5).

Different responses of flower visitors among the plants may occur due to the difference among pollination resources and plant morphology. This study demonstrates that though VR was higher in AC for both honeybee species, they spent more time on the flower of AR. Due to the morning anthesis and odourless flowers, pollination occurs during daytime for flowers of the AR plant. In the nectar of this plant, some non-essential and essential amino acids such as lysine, phenylalanine, threonine, 

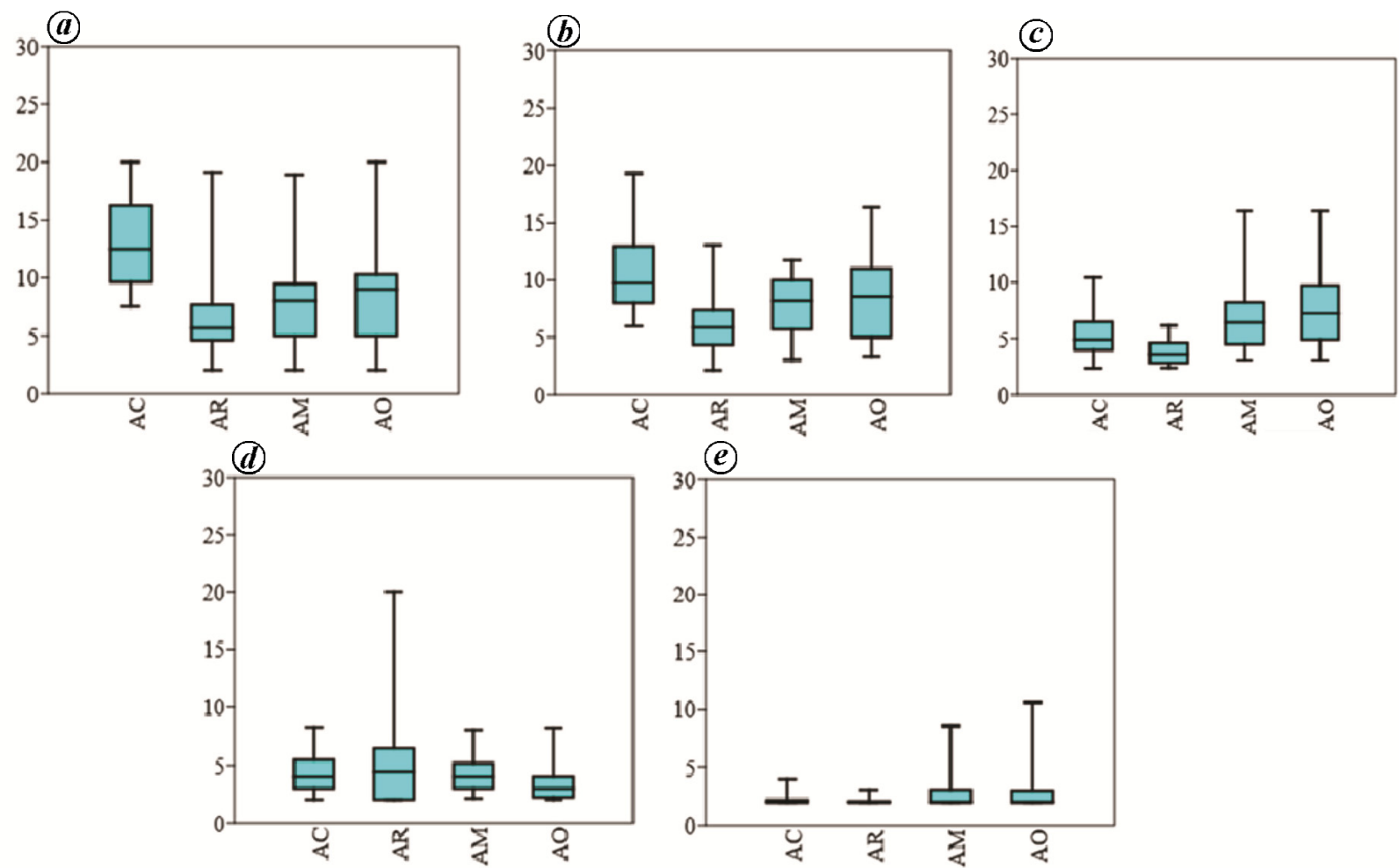

Figure 5. Box plot analysis for visitation rate (VR) of five insect flower visitors among four mangrove plants: $\boldsymbol{a}$, Apis dorsata; $\boldsymbol{b}$, Apis mellifera; $\boldsymbol{c}$, Chrysomya megacephala; $\boldsymbol{d}$, Danaus chrysippus; $\boldsymbol{e}$, Micraspis discolor.
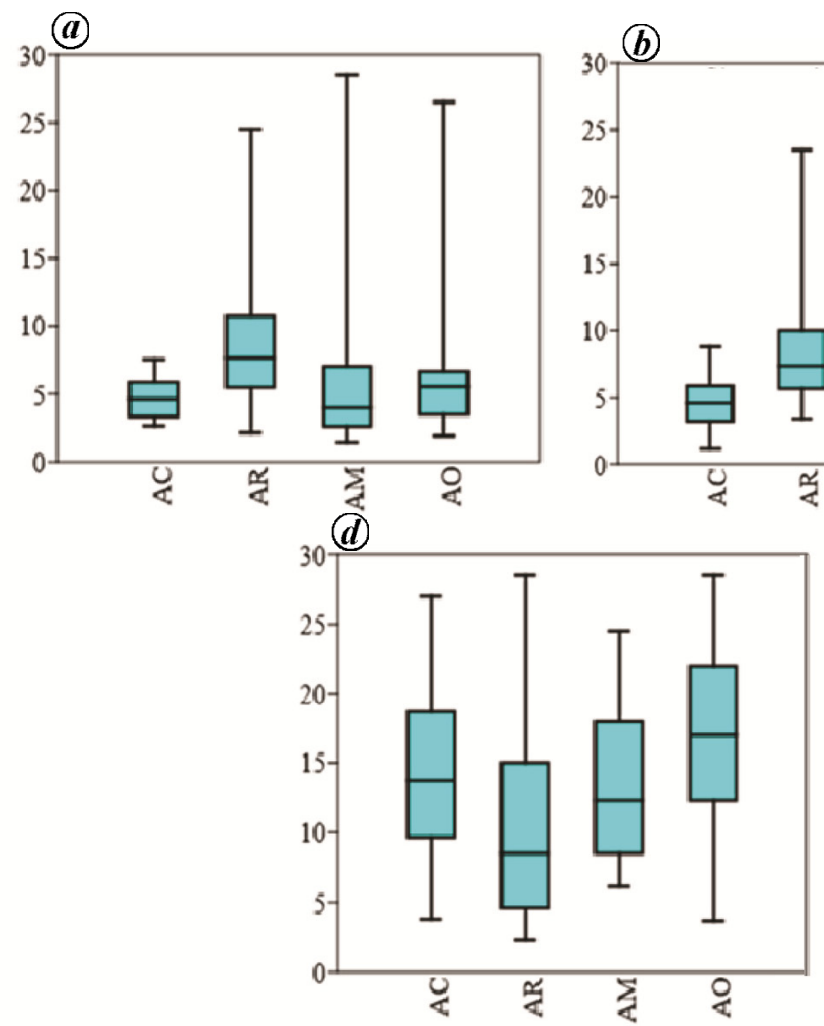
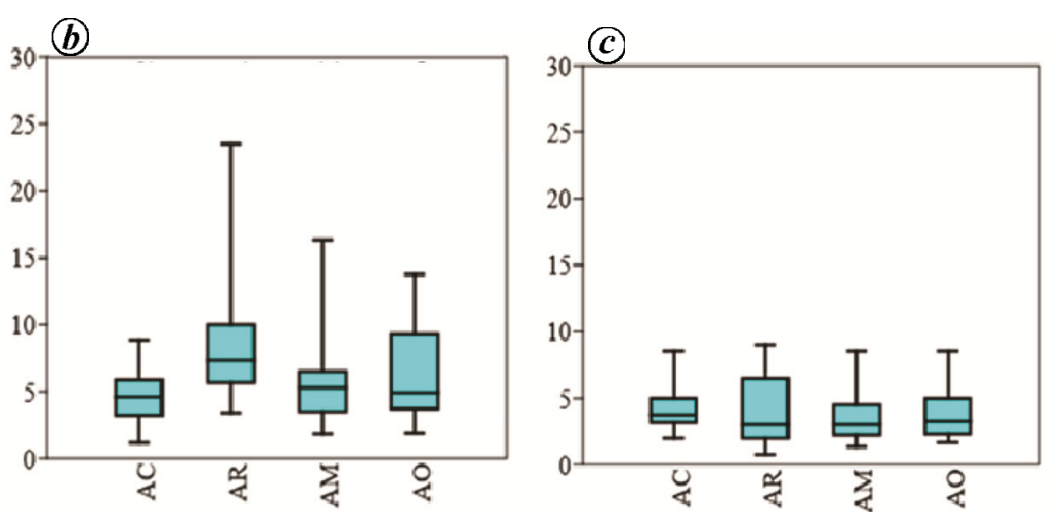

(e)

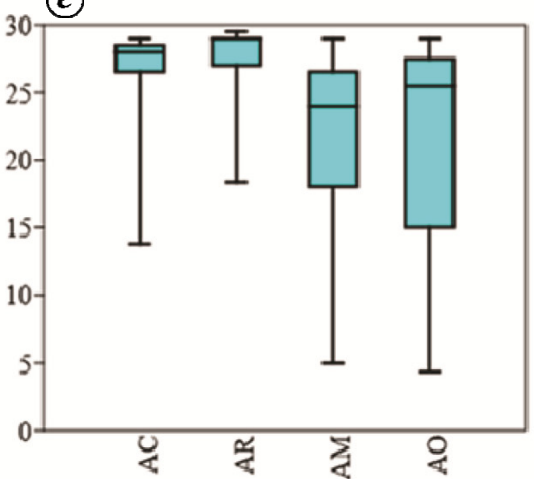

Figure 6. Box plot analysis for handling time (HT) of five insect flower visitors among four mangrove plants: $\boldsymbol{a}$, A. dorsata; $\boldsymbol{b}, A$. mellifera; $\boldsymbol{c}$, C. megacephala $; \boldsymbol{d}$, D. chrysippus; $\boldsymbol{e}$, M. discolor. 
Table 4. One-way ANOVA of plant-specific visitation rate (VR) and handling time (HT) among different insect flower visitors

\begin{tabular}{|c|c|c|c|c|c|}
\hline & Sum of squares & $\mathrm{d} f$ & Mean square & $F$-value & $P<0.05$ \\
\hline \multicolumn{6}{|l|}{ Visitation rate } \\
\hline \multicolumn{6}{|l|}{$\mathrm{AL}$} \\
\hline Between groups & 158.66 & 3 & 52.88 & $28.95 * *$ & 0.00012 \\
\hline Within groups & 14.61 & 8 & 1.82 & & \\
\hline Total & 173.27 & 11 & & & \\
\hline \multicolumn{6}{|l|}{ AR } \\
\hline Between groups & 11.65 & 3 & 3.88 & 3.15 & 0.08 \\
\hline Within groups & 9.85 & 8 & 1.23 & & \\
\hline Total & 21.51 & 11 & & & \\
\hline \multicolumn{6}{|l|}{$\mathrm{AO}$} \\
\hline Between groups & 52.47 & 3 & 17.49 & $23.31 * *$ & 0.0002 \\
\hline Within groups & 6.00 & 8 & 0.75 & & \\
\hline Total & 58.48 & 11 & & & \\
\hline \multicolumn{6}{|l|}{$\mathrm{AM}$} \\
\hline Between groups & 30.04 & 3 & 10.01 & $4.28 * *$ & 0.04 \\
\hline Within groups & 18.69 & 8 & 2.33 & & \\
\hline Total & 48.74 & 11 & & & \\
\hline \multicolumn{6}{|l|}{ Handling time } \\
\hline \multicolumn{6}{|l|}{$\mathrm{AC}$} \\
\hline Between groups & 227.28 & 3 & 75.76 & $44.72 * *$ & 0.00002 \\
\hline Within groups & 13.55 & 8 & 1.69 & & \\
\hline Total & 240.83 & 11 & & & \\
\hline \multicolumn{6}{|l|}{$\mathrm{AR}$} \\
\hline Between groups & 71.43 & 3 & 23.81 & $4.94 * *$ & 0.03 \\
\hline Within groups & 38.54 & 8 & 4.81 & & \\
\hline Total & 109.98 & 11 & & & \\
\hline \multicolumn{6}{|l|}{$\mathrm{AO}$} \\
\hline Between groups & 281.94 & 3 & 93.98 & $24.34 * *$ & 0.0002 \\
\hline Within groups & 30.08 & 8 & 3.86 & & \\
\hline Total & 312.83 & 11 & & & \\
\hline \multicolumn{6}{|l|}{ AM } \\
\hline Between groups & 154.63 & 3 & 51.54 & $7.34 * *$ & 0.01 \\
\hline Within groups & 56.14 & 8 & 7.01 & & \\
\hline Total & 210.78 & 11 & & & \\
\hline
\end{tabular}

The analysis includes VR and HT of four flower visitors $\times$ a single plant. ** Significant at $P<0.05$.

tryptophan, valine and histidine are present and honey bees require some of them. Therefore, these plants may be better adapted for bee pollination, or they show better melittophilous pollination ${ }^{24,36}$. Though the AR plants are reported as bee-pollinated, the present study shows that the activity of lepidopteran insects, specially butterflies was also high (Table 3). D. chrysippus showed the highest VR for this plant. However, dipteran insect activity was very low compared to insects of other orders in this plant. The present study showed that in the two Avicennia plant species (AO and AM), activity of dipteran insect was comparatively higher than the other two plants. The butterfly provided highest HT on AO among the four plants. With the context of previously reviewed literatures, fly pollination is more favourable for both the $A v i$ - cennia species because of their floral morphology. The nectar containing amino acids plays an important role in the interaction between insect and flower ${ }^{12,23}$. Probably hexose-rich nectar of AM may attract the dipteran flower visitors, whereas wasp and butterfly are adaptive to sucrose content of nectar. Among ten essential amino acids that the insects require, arginine, lysine, threonine and histidine are present in the AO plant. Proline and glycine are also present in the nectar of AO plant; and proline stimulates the salt receptor cells in flies ${ }^{32}$. Due to the floral structure, AC plant is compatible with selfpollination, but the present study shows a slightly higher reproductive success in cross-pollination for this plant. Easily accessible resources, i.e. pollen grains and nectar of this plant contribute to a wide range of visitors. 
Table 5. One-way ANOVA of insect flower visitors on their plant-wise VR and HT

\begin{tabular}{|c|c|c|c|c|c|}
\hline & Sum of squares & $\mathrm{d} f$ & Mean square & $F$-value & $P<0.05$ \\
\hline \multicolumn{6}{|l|}{ Handling time } \\
\hline \multicolumn{6}{|l|}{ Apis dorsata } \\
\hline Between groups & 25.94 & 3 & 8.64 & 1.26 & 0.35 \\
\hline Within groups & 54.91 & 8 & 6.86 & & \\
\hline Total & 80.86 & 11 & & & \\
\hline \multicolumn{6}{|l|}{ Apis mellifera } \\
\hline Between groups & 26.79 & 3 & 8.93 & $5.22 * *$ & 0.02 \\
\hline Within groups & 13.66 & 8 & 1.70 & & \\
\hline Total & 40.46 & 11 & & & \\
\hline \multicolumn{6}{|c|}{ Chrysomya megacephala } \\
\hline Between groups & 0.2387 & 3 & 0.07 & 0.05 & 0.982 \\
\hline Within groups & 11.767 & 8 & 1.47 & & \\
\hline Total & 12.005 & 11 & & & \\
\hline \multicolumn{6}{|l|}{ Danaus chrysippus } \\
\hline Between groups & 56.30 & 3 & 18.76 & 2.425 & 0.14 \\
\hline Within groups & 61.92 & 8 & 7.74 & & \\
\hline Total & 118.23 & 11 & & & \\
\hline \multicolumn{6}{|l|}{ Micraspis discolor } \\
\hline Between groups & 93.61 & 3 & 31.20 & 1.98 & 0.19 \\
\hline Within groups & 125.92 & 8 & 15.74 & & \\
\hline Total & 219.53 & 11 & & & \\
\hline \multicolumn{6}{|l|}{ Visitation rate } \\
\hline \multicolumn{6}{|l|}{ Apis dorsata } \\
\hline Between groups & 66.20 & 3 & 22.06 & $5.13 * *$ & 0.02 \\
\hline Within groups & 34.39 & 8 & 4.29 & & \\
\hline Total & 100.60 & 11 & & & \\
\hline \multicolumn{6}{|l|}{ Apis mellifera } \\
\hline Between groups & 40.80 & 3 & 13.60 & $17.81 * *$ & 0.0006 \\
\hline Within groups & 6.10 & 8 & 0.76 & & \\
\hline Total & 46.90 & 11 & & & \\
\hline \multicolumn{6}{|c|}{ Chrysomya megacephala } \\
\hline Between groups & 22.35 & 3 & 7.45 & $11.31 * *$ & 0.0030 \\
\hline Within groups & 5.27 & 8 & 0.65 & & \\
\hline Total & 27.62 & 11 & & & \\
\hline \multicolumn{6}{|l|}{ Danaus chrysippus } \\
\hline Between groups & 4.98 & 3 & 1.66 & $3.932 * *$ & 0.053 \\
\hline Within groups & 3.38 & 8 & 0.42 & & \\
\hline Total & 8.37 & 11 & & & \\
\hline \multicolumn{6}{|l|}{ Micraspis discolor } \\
\hline Between groups & 1.10 & 3 & 0.36 & 1.69 & 0.24 \\
\hline Within groups & 1.74 & 8 & 0.21 & & \\
\hline Total & 2.84 & 11 & & & \\
\hline
\end{tabular}

The analysis includes VR and HT of a single flower visitor $\times$ four plants. ** Significant at $P<0.05$.

\section{Pollination efficiency in relation to pollen carrying capacity}

Pollen carrying capacity of flower visitors is one of the most important factors affecting the plant reproductive success for cross-pollinating plants. Among the five common flower visitors, $A$. dorsata had the ability to carry the highest amount of pollen among all insects in all the plants. While $M$. discolor was found to carry the least amount of pollen for $\mathrm{AC}, \mathrm{AM}$ and $\mathrm{AO}$ plants, whereas for AR plant C. megacephala was observed to carry the least amount of pollen (Table 6).

$M$. discolor has been reported as a potential biological control agent because of its predatory activity ${ }^{37,38}$. Various coccinellids species have been reported as pollen feeders, and the adult $M$. discolor was also found to feed on pollen and prey species ${ }^{39}$. The present study reveals that $M$. discolor has the highest HT and the lowest VR among all the other studied insects. This may be because of its predation or pollen-feeding efficiency. It carries a 
Table 6. Pollen carrying capacity of flower visitors to the studied plants (mean $\pm \mathrm{SE} ; n=10$ for Apis dorsata and Apis mellifera and Chrysomya megacephala and Danaus chrysippus; $n=5$ )

\begin{tabular}{lcccr}
\hline Insect species & AC & AR & AM & AO \\
\hline A. dorsata & $479.6 \pm 76.9$ & $584.1 \pm 79.0$ & $295.8 \pm 38.7$ & $377.5 \pm 47.5$ \\
A. mellifera & $399.0 \pm 51.2$ & $477.6 \pm 53.9$ & $212.4 \pm 23.1$ & $255.7 \pm 33.7$ \\
C. megacephala & $219.1 \pm 30.2$ & $87.2 \pm 9.0$ & $202.7 \pm 26.2$ & $107 \pm 17.9$ \\
D. chrysippus & $113.8 \pm 7.7$ & $157.4 \pm 21.0$ & $77.6 \pm 20.0$ & $103.8 \pm 19.5$ \\
M. discolor & $97.1 \pm 13.2$ & $104.6 \pm 12.9$ & $59.5 \pm 9.0$ & $71.1 \pm 7.0$ \\
\hline
\end{tabular}

$n$, Number of individuals studied.

low amount of pollen, mostly on the ventral side of the body. M. discolor may have the lowest pollination efficiency among the five common flower visitors. Among honeybees, $A$. dorsata and $A$. mellifera were reported to carry a large amount of pollen from each plant, but $A$. dorsata was found to carry the highest amount among all insects (Table 6). The dipteran and lepidopteran insects, e.g. C. megacephala and D. chrysippus both carried moderate amount pollen from each of the plants, whereas in the context of pollen-carrying capacity, C. megacephala carried the lowest amount of pollen for AR plant and $D$. chrysippus carried the lowest pollen for AM plant. $C$. megacephala carried the highest amount pollen for AM plant, and D. chrysippus carried the highest amount of pollen for AR plant (Table 6). Therefore, with respect to quantity of average pollen grains carried by an insect, $A$. dorsata holds the highest position followed by $A$. mellife$r a$ for all the plants.

\section{Conclusion}

The five common flower visitors, viz. A. dorsata, A. mellifera, C. megacephala, D. chrysippus and M. discolor aid in cross-pollination success in all the four mangrove plants (AO, AM, AC and AR) studied here. Both A.dorsata and $A$. mellifera pollinate the four plant species in an efficient manner. Chakrabarty ${ }^{17}$ reported that bees show greater preference for hive towards Avicennia species. $C$. megacephala and D. chrysippus are moderately efficient for the plants. Though $M$. discolor is included with the lowest pollen carrying capacity, its functional role in terms of predation and transferring pollen may help the plants in relation to protection and reproductive success.

Various conservation approaches have been used throughout the world for conserving insect pollinators. In Australia, C. megacephala has been conserved in the process of rearing for use as a pollinator of mango plants ${ }^{40}$. A. mellifera is also reared in apiculture in different parts of the Indian Sundarbans. The proper protection of habitats of insects may help in the conservation of essential insect diversity for this ecosystem. Mangrove is considered as a threatened ecosystem all over the world ${ }^{1}$. The Sundarbans mangrove forest is also exposed to various natural catastrophes like cyclone, tsunami, heavy rainfall and other anthropogenic threats ${ }^{14}$. It has been reported that seven common mangroves of the Sundarbans are threatened and need to be conserved; $\mathrm{AC}$ is one of them and AR is a near threatened species ${ }^{16}$. Therefore, it is essential to protect and conserve the mangroves and flower visitor species because conservation of these insect species is necessary for long-term conservation of this unique mangrove ecosystem.

1. Alongi, D. M., Present state and future of the world's mangrove forests. Environ. Conserv., 2002, 29, 331-349.

2. Giri, C., Ochieng, E. L., Tieszen, L., Zhu, Z., Singh, A., Loveland, T., Masek, J. and Duke, N., Status and distribution of mangrove forests of the world using earth observation satellite data. Global Ecol. Biogeogr., 2010, doi:10.1111/j.1466-8238.2010.00584.x.

3. Mitra, B., Biswas, O., Roy, S. and Chakraborti, U., Pollinators of mangrove in the perspective of Indian Sundarbans. ENVIS Newsl., 2015, 21, 6-11.

4. Therattil, J. J. and Olakkengil, J. L., Diversity and distribution of destructive insects in Chettuvai mangroves, Kerala, India. Millennium Zool., 2011, 12(1), 35-37.

5. Hamilton, R. S. and Snedaker, S. C., Handbook for Mangrove Area Management, Commission on Ecology, IUCN, Gland, Switzerland, 1984.

6. Tomlinson, P. B., The Botany of Mangroves, Cambridge University Press, New York, USA, 1986, p. 413.

7. Primack, R. B., Duke, N. C. and Tomlinson, P. B., Floral morphology in relation to pollination ecology in five Queensland coastal plants. Austrobaileya, 1981, 4, 346-355.

8. Huang, Z. Y. and Giray, T., Factors affecting pollinators and pollination. Psyche, 2012; doi:10.1155/2012/302409.

9. Dupont, Y. L. and Olesen, J. M., Ecological modules and roles of species in healthland plant-insect flower visitor networks. J. Anim. Ecol., 2009, 78, 346-353.

10. Silberbauer-Gottsberger, I. and Gottsberger, G., A polinizacao de plantas do cerrado. Rev. Bras. Biol., 1988, 4, 651-663.

11. Gottsberger, G., How diverse are Annonaceae with regard to pollination? Bot. J. Linn. Soc., 2012, 169, 245-261.

12. Pandit, S. and Choudhury, B. C., Factors affecting pollinator visitation and reproductive success in Sonneratia caseolaris and Aegiceras corniculatum in a mangrove forest in India. J. Trop. Ecol., 2001, 17, 431-447.

13. Pandey, R. and Pandey, C. N., Spatial and temporal variation in floral visitors of a mangrove species - Aegiceras corniculatum (L.) Blanco - in the Marine National Park, Gujarat, India. Int. J. Bot. Res., 2013, 3(1), 35-42.

14. Mahadevi, K. and Vikas, M., Climate change -impact on the Sundarbans: a case study. Int. Sci. J. Env. Sci., 2012, 7-15.

15. Biswas, O., Chakraborti, U., Roy, S., Modak, B. K., Shah, S. K. and Panja, B., First record of Amerila eugenia (Fabricius, 1794) 
(Lepidoptera: Erebidae: Arctiinae) from Eastern India. Ent. Appl. Sci. Lett., 2016, 3(3), 6-9.

16. Barik, J. and Chowdhury, S., True mangrove species of Sundarbans delta, West Bengal, Eastern India. Check List, 2014, 10(2), 329-334.

17. Chakrabarty, K., Sundarbans (India) honey and mangrove swamps. J. Bombay Nat. Hist., 1985, 84(1), 133-137.

18. Naskar, K. and Mandal, R., Ecology and Biodiversity of Indian Mangroves, Part I, Global Status, Daya Publishing House, New Delhi, 1999, p. 783.

19. Bhattacharya, K., Majumdar, M. R. and Bhattacharya, S. G., A Textbook of Palynology (Basic and Applied), New Central Book Agency (P) Ltd, Kolkata, 2006, p. 352.

20. Aluri, R. J. S., Observation on the floral biology of certain mangroves. Proc. Indian Natl. Sci. Acad. Part B, 1990, 56(4), 367374.

21. http://www.bsienvis.nic.in/Database/IndianMangroves_3941.aspx (accessed on 24 November 2017).

22. Ghosh, A., Gupta, S., Maity, S. and Das, S., Study of floral morphology of some Indian mangroves in relation to pollination. Res. J. Bot., 2008, 3, 9-16.

23. Solomon Raju, A. J., Reproductive ecology of mangrove flora: conservation and management. Transylv. Rev. Syst. Ecol. Res., 2013, 15(2), 133-184

24. Solomon Raju, A. J. and Karyamsetty, H. J., Reproductive ecology of Aegialitis rotundifolia Roxb., a crypto-viviparous mangrove plant species in Krishna Mangrove Forest, Andra Pradesh. Transylv. Rev. Syst. Ecol. Res., 2018, 20(1), 17-30.

25. QGIS Development Team, QGIS Geographic Information System. Open Source Geospatial Foundation Project, 2019; http:// qgis.osgeo.org (accessed on 21 January 2019).

26. Jonathan, J. K. and Kulkarni, P. P., Manual: Collection, Preservation and Identification of Insects and Mites of Economic Importance (ed. Tikader, B. K.), Zoological Survey of India, Kolkata, 1986, p. 322.

27. Herra, C. M., Pollinator abundance, morphology, and flower visitation rate: analysis of the quantity component in a plantpollinator system. Oecologia, 1989, 80, 241-248.

28. Meerabai, G., Visitation rate, effectives and efficiency of pollinators to Cadaba fruiticosa (Linn.) Druce. Bioscan, 2012, 7(3), 483485 .

29. Hammer, Ø., Harper, D. A. T. and Ryan, P. D., PAST: paleontological statistics software package for education and data analysis. Palaeontol. Electron., 2001, 4(1), 9; http://palaeo-electronica. org/2001_1/past/issue1_01.html

30. Stephenson, A. G., Flower and fruit abortion: proximate causes and ultimate functions. Annu. Rev. Ecol. Syst., 1981, 12, 253-279.
31. Coupland, G. T., Paling Eric, I. and McGuinness Keith, A., Floral abortion and pollination in four species of tropical mangroves from northern Australia. Aquat. Bot., 2006, 84, 151-157.

32. Solomon Raju, A. J., Subba Rao, P. V., Kumar, R. and Rama Mohan, S., Pollination biology of the crypto-viviparous Avicennia species (Avicenniaceae). J. Threaten Taxa, 2012, 4(15), $3377-$ 3389.

33. Artz, D. A. and Nault, B. A., Performance of Apis mellifera, Bombus impatiens and Peponapis pruinosa (Hymeoptera: Apidae) as pollinators of pumpkin. J. Econ. Entomol., 2011, 104(4), 11531161.

34. Ne'eman, G., Jurgens, A., Newstrom-Lloyd, L., Potts, S. and Dafni, A., A framework for comparing pollinator performance: effectiveness and efficiency. Biol. Rev., 2009, 85, 435-451.

35. Thompson, J. D., How do visitation patterns vary among pollinators in relation to floral display and floral design in a generalist pollination system? Oecologia, 2001, 126, 386-394.

36. DeGroot, A. P., Protein and amino acid requirements of the honey bee (Apis mellifica L.). Physiol. Compar. Oecol., 1953, 3, 197-285.

37. Begum, M. A., Jahan, M., Bari, B. N., Hossain, M. M. and Afsana, N., Potentiality of Micraspis discolor (F.) as a biocontrol agent of Nilaparvata lugens (Stal). OJBS, 2002, 2(9), 630-632.

38. Kumar, M. V. S., Bandyopadhyay, U. K., Lalitha, N. and Saratchandra, B., Biology and feeding efficacy of Micraspis discolor, a potential biological control agent of whitefly. Dialeuropora decempuncta. J. Ent. Zool. Stud., 2017, 6(1), 938-941.

39. Shankar, C., Mohan, M., Sampathkumar, M., Lydia, Ch. and Katti, G., Functional significance of Micraspis discolor (F.) (Coccinellidae: Coleoptera) in rice ecosystem. J. Appl. Entomol., 2012, doi:10.1111/jen.12035.

40. Moophayak, K. and Meeinkuirt, W., Predominance of blow flies (Diptera: Calliphoridae) among insects visiting flowers of Buchanania lanzan (Sapindales: Anacardiaceae). Appl. Ecol. Environ. Res., 2017, 15(4), 651-659.

ACKNOWLEDGEMENTS. K.B. thanks the Department of Science and Technology (DST), West Bengal, Government of India for the financial support (Ref. No. 865/ST/P/S\&T/1G-1/2015). U.C. is supported by a DST-WB grant from DST. We also thank Personal Research Grant, University of Kalyani, 2018-2019 for partial financial support; the Director (Zoological Survey of India, Kolkata), for support and Prof. Animesh Kumar Datta (Department of Botany, University of Kalyani), for help with statistical analysis.

Received 8 February 2019; accepted 11 June 2019

doi: $10.18520 / \mathrm{cs} / \mathrm{v} 117 / \mathrm{i} 6 / 1060-1070$ 